\title{
"As relações internacionais das Sociedades Científicas. Experiências gratificantes"
}

O amável convite da Sociedade Brasileira de Coluna (S.B.C.) e do corpo editorial da revista "Coluna/Columna", numa oportunidade que muito agradecemos, permite-nos chegar junto dos cirurgiões vertebrais brasileiros com um pouco da história da Sociedade Portuguesa de Patologia da Coluna Vertebral (S.P.P.C.V.) que nasceu da vontade de concertação entre numerosos ortopedistas e neurocirurgiões há cerca de nove anos; igualmente nos permite trazer ao conhecimento da comunidade médica brasileira ligada à patologia da coluna aspectos da produção científica portuguesa publicitada no Congresso de Monte Real, Leiria, Portugal em Março de 2012 e sobretudo reafirmar a consideração e amizade que nos merecem os diversos membros da Sociedade Brasileira de Coluna com quem temos privado e construído sólidos alicerces de uma cooperação, diria mesmo, união de vivências e expectativas, a que não sendo alheia a coincidência de língua e cultura se augura promissor futuro.

A vida profissional de qualquer médico, todos concordarão, é fértil em situações gratificantes. Humana, técnica e cientificamente. De facto, não nos esgotamos profissionalmente nos momentos assistenciais com os nossos pacientes, que na senda de Hipócrates, são de relevância máxima; a associação em sociedades científicas traduz a preocupação de nos mantermos actualizados através da audição e discussão interpares, numa lógica de formação contínua, de forma a praticarmos uma Medicina respeitadora do "estado da arte". E este respeito pelo desenvolvimento técnico e científico como indispensável meio de melhor tratar o paciente, esteve decerto na base da criação de qualquer Sociedade Científica, como o esteve na constituição da S.P.P.C.V.

Um curioso artigo, publicado em 1944 no Journal Of Bone And Joint Surgery, que nos chegou às mãos através de amigo e colega ortopedista, inspira-nos sobremaneira. Da autoria de Alan Smith e colaboradores (Hospital e Dispensário Ortopédico de Nova lorque), apresenta resultados do tratamento cirúrgico de 100 casos de hérnia discal lombar, defendendo e cito-o em português "... Acreditamos que todos os casos de ciática deveriam ser estudados por neurocirurgião e ortopedista, trabaIhando em conjunto como equipa, cada um familiar e empático com os pontos de vista do outro." Que atualidade ainda, 68 anos volvidos! Tão adequada esta visão que, da natural articulação, resultou em irreversível expansão o cirurgião vertebral.

Assim sucedeu também em Portugal: em 21 de Novembro de 2003 nasce formalmente a S.P.P.C.V., resultado dos esforços de um grupo de ortopedistas e neurocirurgiões defensores deste comum conceito e que, aumentando a abrangência, concordaram em alargar a participação na Sociedade a clínicos de outras especialidades, nomeadamente, Neuroradiologia, Medicina Física e Reabilitação e Reumatologia.

Desde logo, pelos primeiros órgãos directivos, foi estabelecido um protocolo de cooperação com a SBC. Decisão acertada e visionária, responsável por uma parceria que se tem revelado extremamente gratificante. Pessoalmente, já na presidência da Sociedade Portuguesa de Neurocirurgia havíamos experimentado as virtudes e vantagens recíprocas do estabelecimento de relações estreitas com sociedades científicas nacionais, continentais e intercontinentais e, também naquele caso, privilegiando as brasileiras com consolidado sucesso. É já vulgar dizer que o Atlântico Sul não mais constitui a barreira de outros tempos e que a comunicação via web nos coloca próximos sempre que o desejamos. É verdade e subscrevemos!

Com estes pressupostos, os espaços de cooperação no âmbito da parceria com a SBC são imensos e, dentro das possibilidades, trabalhados pelos órgãos directivos de ambas sociedades disponibilizando reciprocamente os meios ao seu alcance. Aqui reside o gratificante resultado das relações entre sociedades científicas: independentemente da sua dimensão, recursos, influência, norteia-as o acrescer de esforços para assegurar a melhor formação e atualização dos seus membros e consequentes repercussões sobre o bem-estar das comunidades em que exercem.

Vamos continuar.

Em nome da S.P.P.C.V., desejamos à S.B.C. e seus ilustres membros os maiores sucessos. 